Ensuring integrity requires the realization of such a value as order. And order is a special state of the hierarchy of legal values, which corresponds to justice. Legal values exist in an environment of values and order, forming a system that is quite flexible and adaptive. The existence of legal values should be considered the most important factor in the development of law, which fulfills its purpose. Legal values underlie the right, are enshrined and protected by law.

Key words: value, society, classification of values, value orientations, legal values.

DOI: $10.36695 / 2219-5521.2 .2020 .08$

УДК 340.11

\title{
Н.С. ФЕДОРУК
}

Наталія Сергіївна Федорук, кандидат юридичних наук, доцент юридичного фракультету Чернівецького національного університету імені Ю. Федьковича*

ORCID: 0000-0003-1595-0896

\section{ПУБЛІЧНЕ ПРАВО УКРАЇНИ В УМОВАХ ПОСТІНДУСТРІАЛЬНОЇ ДЕРЖАВИ}

Постановка проблеми. Взаємовідносини особи і держави завжди були одним із ключових питань як теорії права, так і галузевих юридичних наук. Необхідність дослідження змін у характері відносин особи і держави пострадянської України є надзвичайно актуальною проблемою насамперед для публічно-правових наук. Це зумовлено особливістю публічно-правових відносин, яка полягає в обов'язковій участі в них суб'єкта владних повноважень шляхом реалізації цих владних повноважень.

Немає сумніву, що взаємовідносини особи і держави можуть мати різний характер, який визначається насамперед типом конкретного суспільства. Сучасна Україна прагне наблизитись до такого типу суспільства, де панують ідеали справедливості, гуманізму та демократії, а люди намагаються гармонізувати відносини між окремою особою та суспільством. Держава в такому суспільстві виступає засобом узгодження інтересів різних соціальних груп, особи і суспільства. Вона підкоряється виключно суспільним інтересам і контролюється суспільством. Права і свободи людини є метою та, водночас, межею втручання держави в суспільне й особисте життя. Утім, певна частина досліджень з теорії права та значна частина досліджень галузевих публічноправових наук продовжує знаходитись під впливом етатистського, а часом відверто позитивістського та патерналістського правового світогляду. Відтак, шляхетні ідеї демократії та людиноцентризму виглядають штучними і часто недолугими «прикрасами» на тлі ще радянських світоглядних конструкцій вітчизняного права (наприклад, спроба поєднати доктрину людиноцентризму та управлінську природу адміністративного права).

Аналіз останніх досліджень і публікацій. Важливі питання досліджуваної проблеми розглядалися в багатьох працях вітчизняних і зарубіжних учених, зокрема, Е. Тоффлера, І.Л. Честнова, Д.М. Азмі, П.М. Рабіновича, О.Ф. Скакун, М.І. Козюбри, С.Л. Лисенкова, В. Горбатенка та ін. Водночас зазначимо, що абсолютна більшість досліджень у галузі публічного права продовжує орієнтуватись на індустріальне, етатистське розуміння держави, яке не відповідає реаліям сьогодення.

Метою статті $є$ визначення напрямів і орієнтирів розуміння сутності права та держави в умовах постіндустріального інформаційного суспільства. У статті автор намагається визначити ознаки сучасної постіндустріальної держави, засади іiі відносин з особою та на підставі цього вивести основи сучасного людиноцентристського праворозуміння публічної влади та права.

Виклад основного матеріалу. Невідповідність окремих положень сучасної доктрини вітчизняного публічного права принципам гуманізму та людиноцентризму, на нашу думку, зумовлена відсутністю належної уваги науковців до проблеми трансформації сутності та функцій сучасної держави як об'єкта дослідження публічно-правових наук, зокрема, закономірностей співвідношення права і публічної влади, суті та меж державного примусу тощо, а також пов'язаних із цим змінами ролі й місця особи у державі нового типу (постіндустріальній державі).

Отже, першочерговою проблемою, яку слід вирішити для обгрунтування юридичних закономірностей взаємодії держави і особи, є визначення змін у самому об'єкті дослідження. У природничих науках об'єкт дослідження - явища навколишнього світу в живій і неживій природі - є сталим, а наукові дослідження лише поглиблюють наявні знання та уявлення про них. Об'єкт дослідження гуманітарних наук - суспільство та пов'язані з ним явища - змінюються з часом. Тому властивості і закономірності явищ, які вважалися правильними в минулому, на певному етапі розвитку суспільства втрачають своє методологічне значення, оскільки об'єкт дослідження зазнав змін і набув нових якостей. Безумовно, це не означає, що ми повинні нехтувати знаннями попередників. Наприклад, таке соціальне явище, як держава, вивчали, Арістотель, Т. Гоббс, Дж. Локк, Г.В. Гегель, К. Маркс. Але вони вивчали «різну» державу, тобто таку, яка на певному етапі історії була сучасною для кожного з цих дослідників. Тому отримані ними знання можуть допомогти скласти уявлення про закономірності розвитку держави як частини суспільства, але не завжди зможуть дати відповіді на питання щодо сутності сучасних суспільних відносин та інститутів.

(C) Н.С. Федорук, 2020

* Nataliia Fedoruk, Ph.D. in Law, Associate Professor, Associate Professor of Yuriy Fedkovich Chernitsy National University 
Радянська наукова традиція розглядала державу як знаряддя для придушення одного класу іншим або як «організацію економічно пануючого класу» тощо. Звичайно, такі погляди на сьогодні визнаються застарілими абсолютною більшістю вітчизняних вчених, які визнають, що в сучасних умовах виключно класовий підхід до розуміння сутності і ролі держави не може бути продуктивним, оскільки в умовах постіндустріального інформаційного суспільства вже не існує чітко визначеної його класової структури. На зміну їй прийшла складна і розгалужена соціальна структура 3 поділом людей на ті чи інші соціальні групи, який здійснюється не лише на основі відношення людей до засобів виробництва, а й на підставі цілого ряду інших критеріїв ${ }^{1}$. Але чи достатньою мірою відповідає розуміння сучасними вітчизняними науковцями держави, іiі ознак та функцій реаліям XXI століття?

Сучасне суспільство визначається західними науковцями як постіндустріальне, постсучасне, посткапіталістичне (пізніше - як інформаційне). У зв'язку з цим була сформована якщо не нова, то значно оновлена парадигма замість класичної, здійснені принципові методологічні зрушення в базисному підході до розуміння сучасного суспільства.

У сучасних умовах постмодерністської реальності стає практично неможливим прагнення представників влади створити цілісну уніфіковану систему управління суспільними процесами, оскільки влада поступово втрачає попередню соціокультурну базу - людей, готових йти на будь-які жертви заради втілення волі, що виходить 3 єдиного центру². Знижується роль бюрократичних форм організації i, навпаки, зростає роль ринкової конкуренції. Методи «наукового управління» змінюються соціальними управлінськими технологіями. Держава все більш неохоче приймає на себе відповідальність за управління економікою і підтримує ринкове та приватне підприємництво, самостійність, конкурентоспроможність.

Основною тенденцією, яка притаманна сучасному постіндустріальному інформаційному суспільству, є те, що економіка втрачає свій статус домінуючої підсистеми суспільства, яка задає умови і правила функціонування всіх інших підсистем. Більш того, виділяються дві інших, настільки ж значних і самостійних в новому суспільстві, підсистем - телекомунікаційна і система освіти ${ }^{3}$. На відміну від звичного нам марксистського розуміння побудови суспільства власність вже не є основним критерієм, а класи - основним елементом його соціальної структури. Класова структура замінюється статусною ієрархією, яка формується вже не на основі професії, а на основі освіти, рівня культури й ціннісних орієнтацій. Саме культурна ідентичність стає основою системи соціальної ієрархії. Вісь соціального конфлікту пролягає тепер не по лінії володіння

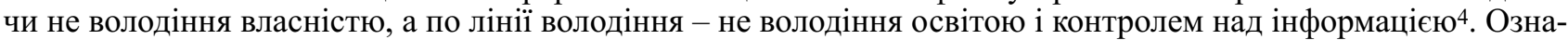
ки держави-нації і права як міри свободи формально рівних індивідів, що випливають 3 конститутивних основ епохи модерну, пов'язаних переважно з обмінним типом суспільних зв'язків, невідворотно змінюються в ситуації постмодерну, як змінюється і тип праворозуміння 5 . 3 феноменологічного погляду право в умовах постмодерну починає розглядатися як притаманне кожному індивідові почуття справедливості, як рівнозначне втілення об'єктивної і суб'єктивної реальності. У герменевтиці право інтерпретується, зокрема, як визнання і повага особистості іншого, визнання за кожним формальної рівності.

Як розуміють сутність держави представники сучасної вітчизняної правової науки? Деякі вчені, продовжуючи радянські традиції, визначають державу як «суверенну, політико-територіальну організацію влади суспільства, яка виражає, узгоджує і забезпечує інтереси населення шляхом встановлення загальнообов'язкових правил поведінки за участю спеціальних органів управління та правового примусу, вирішує загальносуспільні справи і виступає суб' єктом міжнародно-правових відносин»б. Така держава асоціюється 3 «апаратом публічної влади (управління і примусу), який здатний за допомогою права робити свої веління загаль-

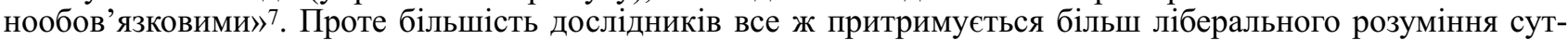
ності держави, зокрема, держава соціально-демократичної орієнтації розуміється як організація публічної влади більшості населення у суспільстві з різноманітними формами приватної та суспільної власності на засоби виробництва, яка постійно поліпшує умови для здійснення основних прав людини, прав нації та народу на засадах свободи, справедливості й солідарності ${ }^{8}$. Юридичні норми в такій державі «забезпечують захист і узгодження суспільних, групових, індивідуальних інтересів зі спиранням, у разі потреби, на легальний примус» ${ }^{9}$, а сама держава «виступає як офіційний представник усього суспільства і забезпечує 3 допомогою спеціального апарату реалізацію своєї політики»10.

Об'єднує всі наведені вище визначення те, що вони відповідають традиційному (індустріальному) розумінню держави як вертикально-інтегрованої системи управління, яка спирається на організоване фізичне, адміністративне, законодавче, ідеологічне та інше насильство, що має чітко виражену ієрархічну структуру з пірамідальним розподілом владних повноважень і встановлює на території свого впливу певні правила (закони), які є обов'язковими до виконання.

Наслідком подібного розуміння держави є особливе праворозуміння, яке ставить в залежність правову відповідальність осіб від їх місця в суспільній ієрархії. Іншими словами, чим вище хтось знаходиться в піраміді влади, тим менше над ним людей, які реально можуть залучити його до відповідальності за ті чи інші дії. Це пояснюється тим, що саме по собі право без офіційної санкції суб'єкта владних повноважень в такій державі не працює.

Як бачимо, усталений у вітчизняній науці погляд на державу і право не повною мірою відповідає сутності постіндустріальної держави, проте цілком відображає риси тієї моделі державно-правових відносин, які ми маємо на сьогодні в Україні і яких прагнемо позбутися (можливо, саме за відсутності відповідного правового світогляду, зусилля науковців і практиків не мають належної ефективності).

На нашу думку, постіндустріальна, людиноцентристська держава є інститутом громадянського суспільства (а саме найвищою формою його організації). У такій державі право $є$ не продуктом державної влади, спрямованим на впорядкування та управління суспільством, а «засобом регулювання та обмеження держав- 
ної влади» 11 , яке «створюється людьми для людської діяльності»12, а сама держава стає активним учасником творення права та гарантом належної реалізації правових норм. Тобто має місце «діалогічність» відносин держави і людини, яка представлена у двох стадіях функціонування політичної системи суспільства - в стадії об'єктивації державної влади при її формуванні («витоках» з суспільства і представництва соціуму) і під час «повернення» державної влади в суспільство у вигляді прийняття владних (у тому числі правових) рішень і їх виконання. Однак не будь-який обмін повідомленнями і діями є діалогом, а тільки такий, який заснований на прийнятті та визнанні (тобто, легітимації, в певному сенсі) точки зору іншого - контрагента (адресата) ${ }^{13}$. Публічна влада постіндустріальної держави вже не односторонній примус, а повноваження суб'єкта на здійснення певних дій чи прийняття рішень, необхідність яких визнана більшістю учасників суспільних відносин, у яких застосовуються владні повноваження. Тобто влада - це своєрідний мандат суспільства наданий певному суб'єкту на прийняття певних рішень та здійснення дій в інтересах всього суспільства, який, у тому числі, включає право на застосування примусу.

Формування публічної влади в постіндустріальній державі визначається, з одного боку, індивідуалізацією особи, іiі безпосередньою участю у спілкуванні з державою та іншими соціальними групами (влада ідентичностей). 3 іншого боку, має місце глобалізація (як наддержавна соціокультурна ідентичність особи), зумовлена високим рівнем інформатизації сучасного суспільства. Подібна «багатовекторність» публічної влади принципово відрізняє постіндустріальну державу від традиційної (індустріальної), де існує єдине джерело «державного управління» - група людей або одна людина, які уособлюють керівництво держави. Перспективи розвитку суспільства в такому випадку ставляться в залежність від волі та здібностей дуже невеликої кількості людей та інститутів.

Разом зі зміною сутності публічної влади в постіндустріальному суспільстві змінюється і суть права: норма стає правом не тому, що акт виданий і забезпечений державою, а тому що така діяльність держави легітимована самим суспільством. Тобто держава постає як один із інструментів правового регулювання (без сумніву, найбільш дієвий та ефективний), але виключно за умови їі суспільної легітимації. Сучасна постіндустріальна держава вже не може розглядатися як система управління, яка діє відповідно до чітких об'єктивних закономірностей і де особі відведена роль об'єкта управлінського впливу. Держава набуває ролі суб'єкта, що забезпечує діалог між різними соціокультурними групами за допомогою права. Звідси випливає і призначення права - як міри дозволеного конкретній особі, яке має вигляд не приписів, а принципів, коли «основне (базове) право акумулює саме принципи, тобто фундаментальні, значущі ... ідейні правила. Зокрема, воно об’єднує в собі основоположні ідеї справедливості, законності, гуманізму, формально-юридичної рівності учасників правового спілкування» ${ }^{14}$.

Висновки. Розуміння сутності сучасної держави, прийняте у вітчизняній науці публічного права, відповідає моделі традиційних (індустріальних) державно-правових відносин, які ми маємо на сьогодні в Україні. Тобто з одного боку, такі знання об' єктивні, оскільки описують властивості та закономірності реального об'єкта правової дійсності - сучасної української держави. Але, з іншого боку, ми маємо запит суспільства на побудову іншої, постіндустріальної, держави, що неможливо зробити, керуючись усталеними ще $з$ радянських часів уявленнями про державу і право. Отже, вітчизняна юридична наука і практика публічного права вимагають повного «перезавантаження» світоглядних концепцій, повної зміни іiі парадигми відповідно до засад людиноцентризму.

1 Теорія держави і права: навч. посіб. / за заг. ред. С.Л. Лисенкова, В.В., Копєйчикова. Київ: Юрінком Інтер, 2002. С. 26.

2 Горбатенко В. Постмодерн і трансформація ціннісної основи людського буття. URL: http://dspace.nbuv.gov.ua/bitstream/ handle/123456789/8725/1-gorbatenko.pdf?sequence $=3$

3 Див.: Тоффлер, Елвін. Третя Хвиля / пер. $з$ англ. А. Євса. Київ: Вид. дім «Всесвіт», 2000.

4 Образ общества в постмодернистсткой социологии. URL: http://www.chem.msu.su/rus/teaching/sociology/5.html

5 Честнов И.Л. Правопонимание в эпоху постмодерна. Правоведение. 2002. № 2. С. 6.

6 Теорія держави та права : навч. посіб. / Є.В. Білозьоров, В.П. Власенко, О.Б. Горова, А.М. Завальний, Н.В. Заяць та ін. Київ : НАВС, Освіта України, 2017. С. 35; Теорія держави і права : навч. посіб. / за заг. ред. Л.М. Стрельбицької. Київ: КондорВидавництво, 2016. С. 26.

7 Теорія держави і права: навч. посіб. Запоріжжя: Просвіта, 2010. С. 35; Теорія держави і права: навч. посіб. / за заг. ред. С.Л. Лисенкова, В.В. Копєйчикова. Київ: Юрінком Інтер, 2002. С. 30.

8 Рабінович П.М. Основи загальної теорії праватаі держави: навч. посіб. Львів: Край, 2007. С. 51.

9 Скакун О.Ф. Теорія держави і права: підручник / пер. 3 рос. Харків: Консум, 2001. С. 39.

10 Загальна теорія держави і права: підручник для студентів юридичних вищих навчальних закладів / М.В. Цвік, О.В. Петришин, Л.В. Авраменко та ін.; за ред. д-ра юрид. наук, проф., акад. АПрН України М.В. Цвіка, д-ра юрид. наук, проф., акад. АПрН України О.В. Петришина. Харків: Право, 2009. С.78.

11 Загальна теорія права: підручник / за заг. ред. М.І. Козюбри. Київ: Ваіте, 2016. С. 103.

12 Там само. С. 48.

13 Честнов И.Л. Постклассическая теория права: монография. Санкт-Петербург: Изд. дом «Алеф-Пресс», 2012. С. $522-526$.

14 Азми Д.М. Структурное строение системы права: теоретико-методологический анализ. Государство и право. 2010. № 6. C. 30 .

\section{Резюме}

Федорук Н.С. Публічне право України в умовах постіндустріальної держави.

У статті досліджено проблему невідповідності сучасної доктрини публічного права принципам гуманізму та людиноцентризму, яка зумовлена відсутністю належної уваги науковців до проблеми трансформації сутності та функцій сучасної держави як об'єкта дослідження публічно-правових наук. У статті досліджувалися закономірності співвідношення права і публічної влади, суті та меж державного примусу, а також пов'язаних з цим змінами ролі і місця особи у державі нового типу (постін- 
дустріальній державі). Визначено, що розуміння сутності сучасної держави, прийняте у вітчизняній науці публічного права, відповідає моделі традиційних (індустріальних) державно-правових відносин, тоді як вітчизняна юридична наука і практика публічного права вимагають зміни існуючих світоглядних концепцій, які би відображали сутність постіндустріальної (інформаційної) держави.

Ключові слова: публічне право, держава, людиноцентризм, публічна влада, індустріальна держава, постіндустріальна держава, інформаційне суспільство.

\section{Резюме}

Федорук Н.С. Публичное право Украины в условиях постиндустриального государства.

В статье исследована проблема несоответствия современной доктрины публичного права принципам гуманизма и человекоцентризма, которая обусловлена отсутствием должного внимания ученых к проблеме трансформации сущности и функций современного государства как объекта исследования публично-правовых наук. В статье исследовались закономерности соотношения права и публичной власти, суть и границы государственного принуждения, а также связанные с этим изменение роли и места человека в государстве нового типа (постиндустриального государства). Определено, что понимание сущности современного государства, принятое в отечественной науке публичного права, соответствует модели традиционных (индустриальных) государственно-правовых отношений, тогда как отечественная юридическая наука и практика публичного права требуют изменения существующих мировоззренческих концепций, которые бы отражали сущность постиндустриального (информационного) государства.

Ключевые слова: публичное право, государство, человекоцентризм, публичная власть, индустриальное государство, постиндустриальное государство, информационное общество.

\section{Summary}

Nataliia Fedoruk. Public Law of Ukraine under the conditions of a post-industrial state.

In this paper the problem of inconsistency between current principle of Public Law and principles of humanity and anthropocentrism, which is defined by the shortage of due diligence of scientists to the problem of essence transformation and functions of modern state as the target of research of Public Law is investigated.

Fundamental beliefs of domestic science of Public Law correspond to the traditional (industrial) awareness of a state as vertically integrated management system, it has an expressive hierarchic structure with a pyramidal distribution of power on the territory of its influence and prescribes certain rules (laws), which are mandatory.

A post-industrial, human-centered state is an institution of civil society (namely, the highest form of its organization), which distinguishes it from a traditional state, where there is a single source of "state administration" - is a group of people or one person who represents the leadership. The act becomes a law not because the act is issued and provided by the state, but because such activity of the state is legitimized by the society. That is, the state appears as one of the instruments of legal regulation, but only under the condition of its public legitimacy. In such a state, law is not the output of governmental power aimed at regulating and managing society, but at the means of regulating and limiting governmental power, which is created by people for human activity, and the state itself becomes an active participant in law-making and guarantor of proper implementation of legal norms.

It has been determined that the awareness of the essence of the modern state in the domestic science of Public Law corresponds to the model of traditional (industrial) state-legal relations, while domestic Legal science and practice of Public Law requires changes in existing fundamental beliefs that would reflect the essence of post-industrial (information) state.

Key words: Public Law, state, anthropocentrism, public power, industrial state, post-industrial state, information society.

DOI: 10.36695/2219-5521.2.2020.09

УДК 349.3(043.2)

\section{ХАЛИДА АЛИСОЙ}

Халида Алисой, диссертант Института права и прав человека НАН Азербайджана*

\section{РАЗВИТИЕ ПРАВА НА СОЦИАЛЬНОЕ ОБЕСПЕЧЕНИЕ: ОПЫТ ЕВРОПЕЙСКИХ СТРАН}

Постановка проблемы и ее актуальность. В результате долгосрочной реализации социально ориентированной и социально ответственной политики страны Западной Европы приобрели интересный социальный опыт, который может быть полезен и для новых независимых государств, включая Азербайджанскую Республику. Несмотря на некоторые различия между европейскими странами, все они заявили о своей приверженности к так называемой социальной модели и европейским гуманитарным ценностям, интересам и правам человека. Такая модель основана на «капитализме», который сами европейцы определяют как «солидарность». Фактически страны Западной Европы обязались соблюдать баланс между экономическим ростом и социальной справедливостью ${ }^{4}$.

Хотя отдельные цели этой системы четко не разделены, они, по крайней мере, частично обусловлены. Без обеспечения материальных потребностей трудно участвовать в жизни общества, трудно обеспечить социальную сплоченность ${ }^{3}$.

* Khalida Alisoy, Ph.D. Candidate of the Institute of Law and Human Rights of the NAS of Azerbaijan 